\begin{tabular}{|c|c|c|}
\hline & Int.J.Curr.Microbiol.App.Sci (2021) 10(09): 600-612 & \\
\hline & $\begin{array}{l}\text { International Journal of Current Microbiology and Applied Sciences } \\
\text { ISSN: 2319-7706 Volume } 10 \text { Number } 09 \text { (2021) } \\
\text { Journal homepage: http://www.ijcmas.com }\end{array}$ & 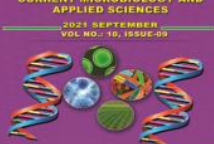 \\
\hline $\begin{array}{l}\text { EXCELLENT } \\
\text { PUBLISHERS }\end{array}$ & & \\
\hline
\end{tabular}

\title{
Control of Papaya Rot Disease by Using Exophytic and Endophytic Fungi Which is Environmentally Friendly
}

\author{
I Made Sudarma*, Ni Nengah Darmiati and dan Ni Wayan Suniti \\ Department of Agroecotechnology Study Program, Faculty of Agriculture, Udayana \\ University Jl. PB. Sudirman Denpasar-Bali, Indonesia
}

*Corresponding author

\section{A B S T R A C T}

\section{Keywords}

Papaya fruit

disease, inhibition, microscopic identification, diversity index

\section{Article Info}

Accepted:

25 August 2021

Available Online:

10 September 2021
Papaya fruit disease has not been known with certainty the cause of the disease, and until now the appropriate control strategy has not been determined. The results of microscopic identification of rot disease in papaya fruit caused by the fungus Lasiodiplodia theobromae. The most exophytic fungi found in the study were Rhizopus sp. as many as 69 isolates, followed by Aspergillus niger as many as 6 isolates, only Actinomyces israelii only 6 isolates while the other Actinomycetes (Actinomadura cremea, Streptomeces sp., and Micromonospora sp.) each had one isolate. While the endophytic fungi were found Rhizopus sp. as many as 30 isolates, followed by $A$. niger with 18 isolates, and finally Agromyces ramosus (Actinomycetes) and Trichoderma sp, each with 3 isolates. The highest prevalence was obtained from the fungus Rhizopus sp. The diversity index and the dominance index on exophytic microbes were 2.45 and 0.4078 , respectively. The index of diversity and dominance of endophytic microbes were 1.876 and 0.58 , respectively. The results of the analysis of the inhibitory power of exophytic and endophytic microbes in vitro, it turns out that almost all have competitive inhibition as well as Trichoderma sp. which has a zone of inhibition means that it is antibiotic and also competitive. Most Actinomycetes have no inhibitory power against pathogens (L.theobromae). The results of the in vivo inhibition test showed that the highest and best inhibitory power was obtained from treatment E (Trichoderma sp.).

\section{Introduction}

Papaya postharvest diseases are often found in traditional markets and super markets, which in principle can originate from the garden (field), and can also come from storage and transportation. All diseases cause the appearance of the fruit that is not good and quickly rots so that the aroma is unpleasant, even difficult to consume. There are many known fungal diseases on papaya fruits, including: Rhizopus (Rhizopus stolonifer Lind.) or black rot, Anthracnose (Colletotrichum gloeosporioides (Penz) Sacc), and Phytophthora ( $P$. parasitica) fruit diseases (Ventura el al., 2004; Indriyani et al., 2008). 
However, Misra and Prakash (2016) stated that postharvest diseases that have damaged papaya fruit are as follows, Rhizopus (watery fruit rot) disease, Fusarium fruit rot, Fusarium soft rot, Fusarium white rot, Ceratocystis black rot, and Hyalodendron soft rot. Efforts to control fungal diseases can be done by utilizing exophytic and endophytic fungi. Endophytic fungi are fungi that grow in plant tissues while exophytic fungi are surface fungi that can live saprophytically but do not cause disease in plants. Phylloplan fungus is a mycota fungus that grows on plant surfaces (Langvard, 1980). There are groups of phylloplan mushrooms: resident (stay silent) and casual (coincidentally). Residents can reproduce on healthy leaf surfaces without being noted to affect the host whereas casuals land on leaf surfaces but are unable to grow. The results of the research by Sudarma et al., (2019) stated that exophytic and endophytic fungi can suppress the pathogenic ability of red wine both in vitro and in vivo. The results of the latest research from Sudarma et al., (2020) stated that the exophytic fungi found such as Aspergillus flavus, A. niger and Rhizopus sp. can suppress manganese rot disease caused by Lasiodiplodia theobromae both in vitro and in vivo.

\section{Materials and Methods}

\section{Place and time of research}

The research was carried out in two places: 1) looking for sick and healthy fruit specimens from the Batubulan market and supermarkets. 2) Laboratory of Plant Diseases and Agricultural Biotechnology Laboratory. The research was carried out from April to August 2021.

\section{Disease Study}

Diseased fruit taken from traditional markets and supermarkets, first studied about the symptoms of the disease, then isolated the pathogen by slicing the part between the symptomatic and asymptomatic fruit and put it in a Petri dish. After two to three days of observing Petri dishes, the growing mycelia were then transferred to new Petri dishes that already contained PDA with the antifungal Livoplaxacin. After growing, it was tested for pathogenicity and tested microscopically.

\section{Isolation of Endophytic and Escophyte Fungi}

Isolation of endophytic fungi, health fruit parts, washed with sterile running water, then the plant parts were sterilized with $0.525 \%$ sodium hypochlorite for 3 minutes, and $70 \%$ alcohol for 2 minutes, then rinsed with sterile water for 1 minute and then placed on the media. PDA (which was first given an antibacterial antibiotic, namely livoploxacin with a concentration of $0.1 \%(\mathrm{w} / \mathrm{v})$. The fungus that emerged from the fruit partswas transferred to a test tube containing PDA to be stored and classified by morphospecies. While exophytic fungi can be done by spraying fruit parts. The washing water is collected, then in a tube, then taken, from a $1 \mathrm{ml}$ tube it is grown into a PDA which has previously been filled with livoploxacin with a concentration of $0.1 \%$ (w/v).

\section{Identification of Endophytic and Exophytic Fungi}

The stored endophytic and exophytic fungi were then grown in Petri dishes containing PDA and repeated 5 times. Cultures were incubated in the dark at room temperature $\left( \pm 27^{\circ} \mathrm{C}\right)$.

Isolates were identified macroscopically after 3 days of age to determine colony color and growth rate, and microscopic identification to identify septa on hyphae, spore/conidia shape and sporangiophores. Fungal identification 
using reference book Samson et al., 1981; Pitt and Hocking, 1997; Barnett and Hunter, 1998; Indrawati et al., (1999).

Inhibition Ability Test of Endophytic and Exophytic Fungi against Pathogens

The endophytic and exophytic fungi that were found were tested for their inhibition against the growth of pathogenic fungi using the dual culture technique (in one Petri dish, one pathogenic fungus was grown each flanked with two endophytic fungi). The inhibitory power can be calculated as follows (Dollar, 2001; Mojica-Marin et al., 2008):

Inhibition ability (\%)

$$
=\frac{\text { A - B }}{\text { A }}
$$

Where: $\mathrm{A}=$ pathogen colony diameter in single culture (mm)

$\mathrm{B}=$ pathogen colony diameter in dual culture (mm)

\section{Endophytic and Exophytic Fungal Prevalence}

Determining the prevalence of endophytic and exophytic fungi was based on the frequency of endophytic and exophytic fungal isolates found in healthy fruit per Petri dish, divided by all isolates found times $100 \%$. The prevalence of isolates will determine the dominance of endophytic fungi present in healthy mango fruit.

\section{Determining Diversity and Dominance Index}

The diversity and dominance index can be determined by calculating the ShannonWiener diversity index (Odum, 1971) and the microbial dominance is calculated by calculating the Simpson index (Pirzan and Pong-Masak, 2008).

$$
\mathrm{H}^{\prime}=-\sum_{\mathrm{i}=1}^{\mathrm{s}} P i \ln P i .
$$

Where:

$\mathrm{H}^{\prime}=$ Shannon-Wiener diversity index

$S=$ Number of genus

$\mathrm{Pi}=\mathrm{ni} / \mathrm{N}$ as the proportion of the ith species ( $\mathrm{ni}=$ the total number of individuals of the total microbial species $\mathrm{i}, \mathrm{N}=$ the total number of individuals in the total $\mathrm{n}$ )

The criteria used to interpret the diversity of Shannon-Wiener (Ferianita-Fachrul et al., 2005) are: $H^{\prime}$ value $<1$, meaning low diversity, $\mathrm{H}^{\prime}$ value $1-3$ means diversity is moderate and $\mathrm{H}^{\prime}$ value $>3$ means diversity is classified as tall.

\section{Dominance Index}

Microbial dominance index was calculated by calculating the Simpson index (Pirzan and Pong-Masak, 2008), with the following formula:

$$
\mathrm{C}=\sum_{\mathrm{i}=1}^{\mathrm{s}} P i^{2}
$$

Where

$\mathrm{C}=$ Simpson's index

$\mathrm{S}=$ Number of genus

$\mathrm{Pi}=$ ni/ $\mathrm{N}$ i.e. the proportion of individuals of type $\mathrm{i}$ and all individuals $(\mathrm{ni}=$ total number of individuals of species $\mathrm{i}, \mathrm{N}=$ number of all individuals in total $\mathrm{n}$ ). 
Furthermore, the dominance index (D) can be calculated using the $1-\mathrm{C}$ formulation $(\operatorname{Rad} e t$ al., 2009).

The criteria used to interpret the dominance of soil microbial species are: close to $0=$ low index or lower dominance by one microbial species or no species that extremely dominates other species, close to $1=$ large index or tend to be dominated by several microbial species (Pirzan and Pong-Cook, 2008). The dominance index was classified into three groups, namely $0<\mathrm{D} 0.5$ (low dominance), $0.5<\mathrm{D} 0.75$ (moderate dominance), and 0.75 < D 1.0 (high dominance) (Rahmawati et al., 2020).

\section{Invivo Antagonist Test}

In vivo antagonistic test of endophytic and exophytic fungi found by pricking fresh fruit with a spelden needle 10 times, then smeared with antagonistic fungal spores (spores of one Petri dish in $250 \mathrm{ml}$ of sterile distilled water), then immersed in fungal spore suspension. pathogens. Endophytic and exophytic fungi found include:

$\mathrm{A}=$ antagonist treatment 1 (spore suspension $5 \times 10^{7}$ )

$\mathrm{B}=$ antagonist treatment 2 (spore suspension $5 \times 10^{7}$ )

$\mathrm{C}=$ antagonist treatment 3 (spore suspension $5 \times 10^{7}$ )

$\mathrm{D}=$ antagonist treatment 4 (spore suspension $5 \times 10^{7}$ )

$\mathrm{E}=$ antagonist treatment 5 (spore suspension $5 \times 10^{7}$ )

$\mathrm{K}-\mathrm{P}=$ control without pathogen

$\mathrm{K}+\mathrm{P}=$ control with pathogen
All treatments were repeated 5 times. The experiment was designed with a randomized block design (RAK), and after the analysis of variance (ANOVA) was carried out, it was continued with the smallest significant difference test (LSD) at the 5\% level. Attack parameters measured by the formulation: the number of stabs attacked by the fungus divided by the total number of punctures $(20$ $\mathrm{x})$ times $100 \%$.

\section{Results and Discussion}

\section{Disease Study}

Symptoms of the disease that can be observed are rot on the skin of the fruit accompanied by the growth of mycelia, white color that covers the surface of the fruit, the rot expands over time (Figure 1A), and when compared with healthy fruit, the skin looks smooth and fresh (Figure 1B). After being isolated, it turned out that the mycelia grew rapidly, three days after the inoculation had covered the Petri dish (Figure 1C). After being observed under a microscope and compared with several existing references, it turned out that the pathogen was Lasiodiplodia theobromae (Figure 1D). Lesiodiplodia theobromae is a pathogen that mostly attacks the fruit of postharvest crops such as mango (Sudarma et al., 2020), and sugar apple (Sudarma et al., 2018).

\section{Exophytic and Endophytic Fungi}

The most exophytic fungi found in the study were Rhizopus sp. as many as 69 isolates, followed by Aspergillus niger as many as 6 isolates, only Actinomyces israelii only 6 isolates while the other Actinomycetes (Actinomadura cremea, Streptomeces sp., and Micromonospora sp.) each had three isolates. While the endophytic fungi were found Rhizopus sp. as many as 30 isolates, followed by $A$. niger with 18 isolates, and finally 
Agromyces ramosus (Actinomycetes) and Trichodermasp, each with 3 isolates (Table 1; Figure 2, 3).

\section{Exophytic and Endophytic Microbial Diversity and Dominance Index}

The diversity index and the dominance index on exophytic microbes were 3.5487 and 0.4078 , respectively. According to Table 2 (Tauruslina et al., 2015 and Ferianita-Fachrul et al., 2005) stated that with the criteria as mentioned above, the scale of 5 is in the very good category (Rahmawati et al., 2020). However, the highest prevalence was produced by the fungus Rhizopus sp. of 69 isolates (Table 3).

The index of diversity and dominance of endophytic microbes were 3.103 and 0.574, respectively (Table 3 ). This means that the diversity index is included on a scale of 5 , with a very good category and the condition of the community structure is very stable (Tauruslina et al., 2015). While the dominance index of 0.574 means the medium category $(0.5<\mathrm{D} 0.75)$, only dominated by the fungus Rhizopus sp. of 30 isolates.

\section{Inhibition Ability of Exophytic and Endophytic Microbes In vitro}

The results of the analysis of the inhibition ability of exophytic and endophytic microbes turned out that almost all of them had competitive inhibition as well as Trichoderma sp. which has a zone of inhibition means that it is antibiotic and also competitive. Most of the Actinomycetes that do not have inhibitory power against pathogens (L. theobromae) (Table 4). The highest inhibition ability on exophytic microbes was isolate Rhizopus sp. 22 of $96.30 \pm 6.4 \%$, while the smallest by isolate Rhizopus sp. 15 and Rhizopus sp. 17 respectively $79.20 \pm 3.2 \%$. Meanwhile, the highest endophytic microbes were achieved by isolates of Trichoderma sp. by $96.30 \pm 6.4 \%$, and the smallest by isolates of Rhizopus sp. 2 with an inhibition ability of $82.59 \pm 6.4 \%$ (Table 4, Figure 4).

According to Diana (2018) stated that Rhizopus sp. is a pathogen in post-harvest papaya where the fungus contaminates or is dominated by orange papaya fruit (Carica papaya L.) with a percentage of half being attacked by the fungus Rhizopus sp.

The number of Rhizopus sp. both exophytic and endophytic ones indicated that the papaya fruit taken as samples was contaminated with the fungus Rhizopus sp. According to Adriani (2010) stated that Rhizopus stolonifer can attack strawberries originating from Jorong Taratak Baru, Kanagarian Salimpek, Solok Regency and Pasar Raya Padang with an attack percentage of $24 \%$.

The fungus Rhizopus sp. Besides attacking the commodities mentioned above, it also attacks apples (Malus sylvestris), avocados (Parsa americana), grapes (Vitis vinivera), longan (Nephelium sp.), Duku (Lansium domesticum), Sawo (Manilkara archras), Oranges (Citrus auranticum) and watermelon (Citrylus lanatus) (Aminah and Supraptini, 2003).

There are several types of Rhizopus fungi that cause damage in the form of fruit rot which has many variants (Hurban Hydroponics, ny).

This fungus Rhizopus nigricans causes fruit rot and is known in all citrus production centers in the world. Early symptoms of this disease are pale yellow or slightly wrinkled patches. The spots develop into rot then the fruit is covered with mycelia and other fungal fruiting bodies. The rotten fruit is finally coated with black and gray thin flour.

Rhizopus stolonifer is the fungus that causes papaya rot. Only attacks ripe fruit that has 
been injured. Whole, healthy and unharmed unripe fruit will not be attacked. Unlike the Phytophthora fungus which can attack fruit at all levels of maturity and unharmed fruit.

Rhizopus cirxinans and $R$. arrchizus both of these fungi cause hull rot on almonds in
California and Australia. Infection occurs when the skin of the fruit breaks and cracks. This cracked skin becomes a patchwork of irregular and slimy patches. This tissue then dies causing crimped groove defects in the fruit.

Table.1 Population of exophytic and endophytic fungi

\begin{tabular}{|c|c|c|c|c|}
\hline No. & $\begin{array}{c}\text { Name of exophytic } \\
\text { microbe }\end{array}$ & $\begin{array}{l}\text { Number of } \\
\text { isolate }\end{array}$ & $\begin{array}{c}\text { Nameof endophytic } \\
\text { microbe }\end{array}$ & Number of isolate \\
\hline $\mathbf{1}$ & Rhizopus sp. & 69 & Aspergillus niger & 18 \\
\hline 3 & Aspergillus niger & 6 & Rhizopus sp. & 30 \\
\hline 4 & Actinomyces israelii & 6 & Agromyces ramosus & 3 \\
\hline 5 & Actinomadura cremea & 3 & Trichoderma sp. & 3 \\
\hline 6 & Streptomeces sp. & 3 & & \\
\hline 7 & Micromonospora sp. & 3 & & \\
\hline
\end{tabular}

Table.2 Environmental quality weighting criteria (Tauruslina et al., 2015)

\begin{tabular}{|c|c|c|c|}
\hline Diversity index & $\begin{array}{c}\text { Condition of } \\
\text { community structure }\end{array}$ & Category & Scale \\
\hline $\mathbf{2}, \mathbf{4 1}$ & Very stable & Very good & 5 \\
\hline $\mathbf{- 2 , 4}$ & More stable & good & 4 \\
\hline $\mathbf{1 , 2 1}-\mathbf{1 , 8}$ & Stable enough & Currently & 3 \\
\hline $\mathbf{0 , 6 1}-\mathbf{1 , 2}$ & Less stable & Bad & 2 \\
\hline$<\mathbf{0 , 6}$ & Unstable & Very bad & 1 \\
\hline
\end{tabular}

Table.3 Diversity and dominance index of exophytic and endophytic microbe

\begin{tabular}{|c|c|c|}
\hline Criteria & Exophytic & Endophytic \\
\hline Diversity index (H) & 3,549 & 0,408 \\
\hline Dominance index (D) & 3,103 & 0,574 \\
\hline
\end{tabular}


Table.4 Inhibition ability of exophytic and endophytic microbe

\begin{tabular}{|c|c|c|c|c|}
\hline No. & $\begin{array}{c}\text { Name of exophytic } \\
\text { microbe }\end{array}$ & $\begin{array}{c}\text { Inhibition ability } \\
(\%)\end{array}$ & $\begin{array}{c}\text { Nameof endophytic } \\
\text { microbe }\end{array}$ & $\begin{array}{c}\text { Inhibition ability } \\
(\%)\end{array}$ \\
\hline 1 & Rhizopus sp. 1 & $83.33 \pm 5.6$ & Aspergillus niger1 & - \\
\hline 2 & Rhizopus sp. 2 & $85.18 \pm 3.2$ & Rhizopus sp. 1 & - \\
\hline 3 & Aspergillus niger 1 & - & Rhizopus sp. 2 & $82.59 \pm 6.4$ \\
\hline 4 & Rhizopus sp. 3 & $85.18 \pm 3.2$ & Rhizopus sp. 3 & - \\
\hline 5 & Rhizopus sp. 4 & $83.33 \pm 5.6$ & Rhizopus sp. 4 & $83.33 \pm 5.6$ \\
\hline 6 & Rhizopus sp. 5 & $90.74 \pm 8.5$ & Rhizopus sp. 5 & $92.59 \pm 6.4$ \\
\hline 7 & Rhizopus sp. 6 & $92.59 \pm 6.4$ & Agromyces ramosus & - \\
\hline 8 & Rhizopus sp. 7 & $90.74 \pm 8.49$ & A. niger 2 & - \\
\hline 9 & Rhizopus sp. 8 & - & A, niger3 & $85.18 \pm 3.2$ \\
\hline 10 & Rhizopus sp. 9 & - & A. niger4 & - \\
\hline 11 & Rhizopus sp. 10 & $83.33 \pm 5.6$ & A. niger 5 & - \\
\hline 12 & Rhizopus sp. 11 & $85.19 \pm 6.4$ & A. niger6 & - \\
\hline 13 & Rhizopus sp. 12 & $85.19 \pm 6.4$ & Rhizopus sp. 6 & $85.19 \pm 6.4$ \\
\hline 14 & Actinomyces israelii & - & Rhizopus sp. 7 & $85.18 \pm 3.2$ \\
\hline 15 & Rhizopus sp. 13 & $87.03 \pm 3.2$ & Rhizopus sp. 8 & $86.30 \pm 2.8$ \\
\hline 16 & Rhizopus sp. 14 & $83.33 \pm 5.6$ & Trichoderma sp. & $96.30 \pm 6.4$ \\
\hline 17 & Rhizopus sp. 15 & $79.20 \pm 3.2$ & Rhizopus sp. 9 & $83.33 \pm 5.6$ \\
\hline 18 & Rhizopus sp. 16 & $84.44 \pm 1.3$ & Rhizopus sp. 10 & $92.59 \pm 6.4$ \\
\hline 19 & Rhizopus sp. 17 & $79.20 \pm 3.2$ & & \\
\hline 20 & Rhizopus sp. 18 & $85.40 \pm 3.2$ & & \\
\hline 21 & Actinomadura cremea & - & & \\
\hline 22 & Streptomeces sp. & - & & \\
\hline 23 & Micromonospora sp. & $85.19 \pm 6.4$ & & \\
\hline 24 & Actinomyces israeli & - & & \\
\hline 25 & Rhizopus sp. 19 & $92.59 \pm 6.4$ & & \\
\hline 26 & A. niger 2 & $81.48 \pm 6.4$ & & \\
\hline 27 & Rhizopus sp. 20 & $92.59 \pm 6.4$ & & \\
\hline 28 & Rhizopus sp. 21 & $88.89 \pm 11.1$ & & \\
\hline 29 & Rhizopus sp. 22 & $96.30 \pm 6.4$ & & \\
\hline 30 & Rhizopus sp. 23 & $92.59 \pm 6.4$ & & \\
\hline
\end{tabular}

Table.5 Inhibition ability of exophytic and endophytic fungi

\begin{tabular}{|c|c|c|c|}
\hline Treatment & Inhibition ability (\%) & LSD 5\% & LSD 1\% \\
\hline A (Endo III.4) Trichoderma sp. & $95 \pm 4.47$ & A & A \\
\hline B (Exo III.10) Rhizopus sp. 10 & $67 \pm 4.00$ & C & C \\
\hline C (Endo II.3) A, niger & $82 \pm 2.44$ & B & B \\
\hline D (Exo III.9) Rhizopus sp. 9 & $54 \pm 3.74$ & D & D \\
\hline E (Exo I.7) Rhizopus sp. 7 & $52 \pm 2.45$ & E & E \\
\hline F (K+P) & $17 \pm 4.00$ & F & F \\
\hline G (K-P)_ & $94 \pm 3.74$ & A & A \\
\hline
\end{tabular}


Fig.1 Observations of disease symptoms (A), healthy papaya (B), pathogenic fungal mycelium in Petri dishes $(\mathrm{C})$, and pathogen microscopic test results $(\mathrm{k}=$ conidia, and $\mathrm{m}=$ mycelium $)$
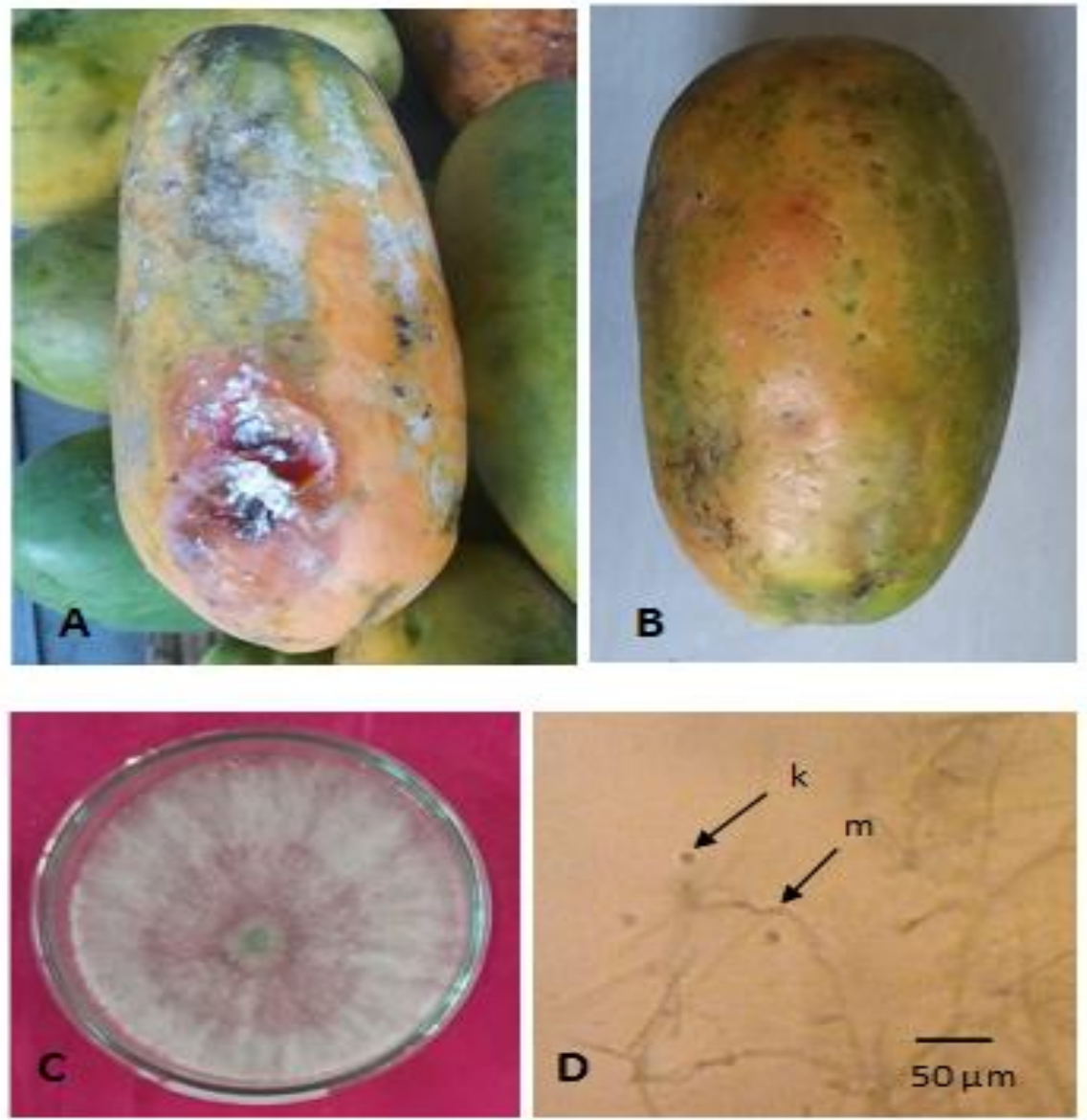

Fig.2 Population of exophytic microbe

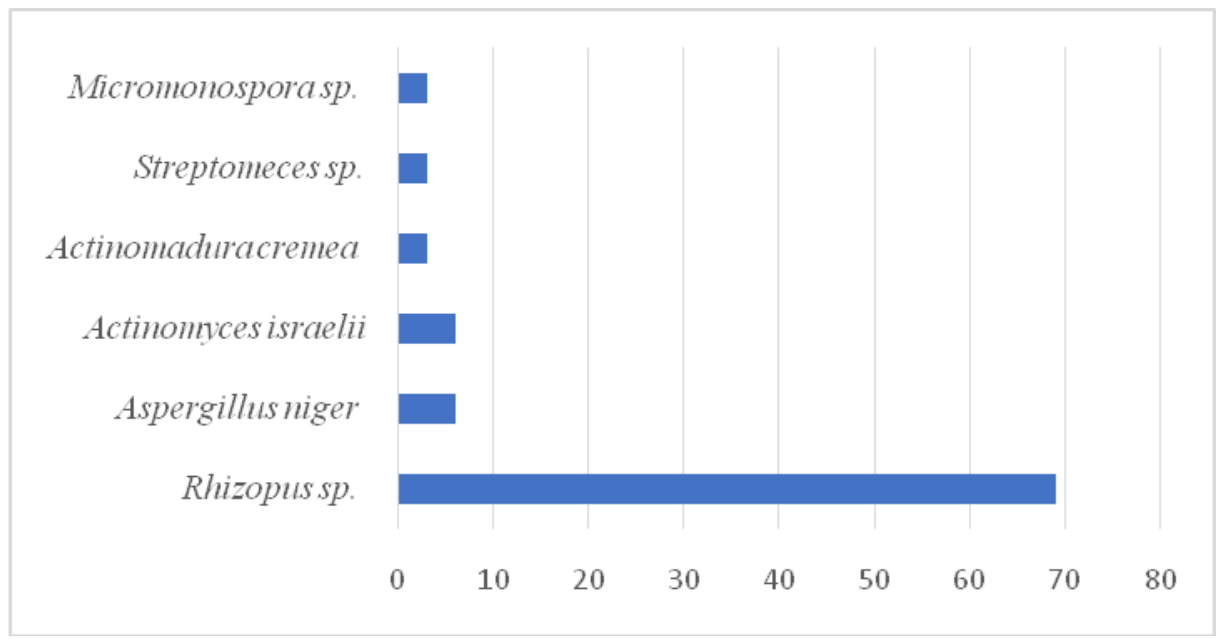


Fig.3 Population of endophytic microbe

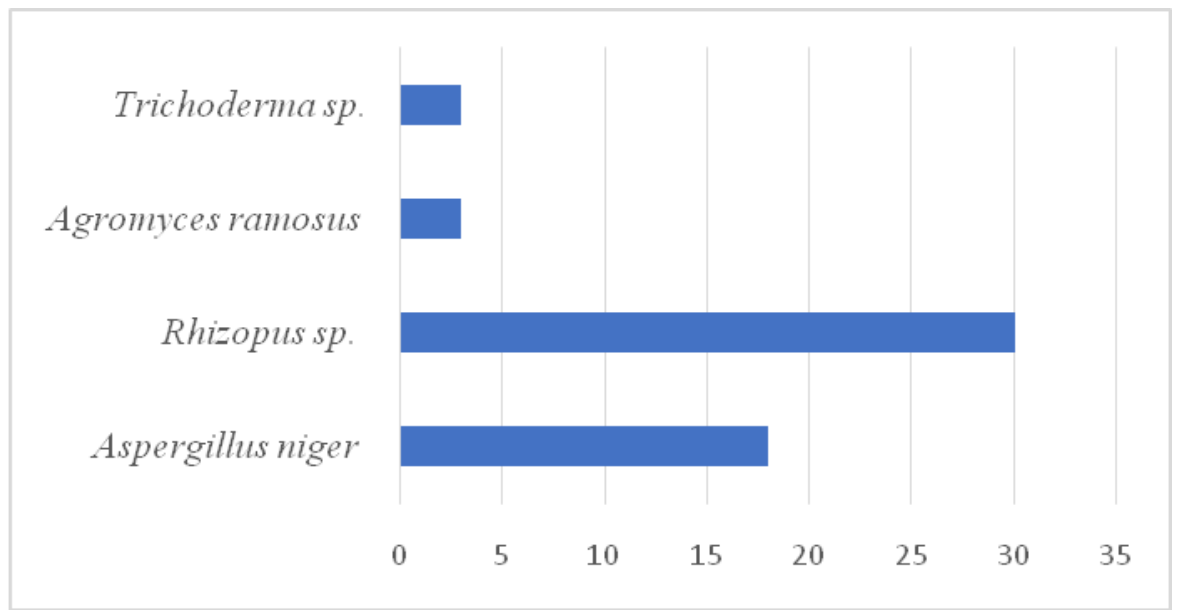

Fig.4 Inhibitory test of some of the best isolates, $\mathrm{A}=$ Trichoderma sp. (Endo III,4), B = Rhizopus sp. (Exo III,9), C = Rhizopus sp. (Exo III.10), D = Rhizopus sp. 7 (Exo I.7), E = Aspergillus niger (Endo II.3) and $\mathrm{F}=$ Lasiodiplodia theobromae (control), 2 days after inoculation
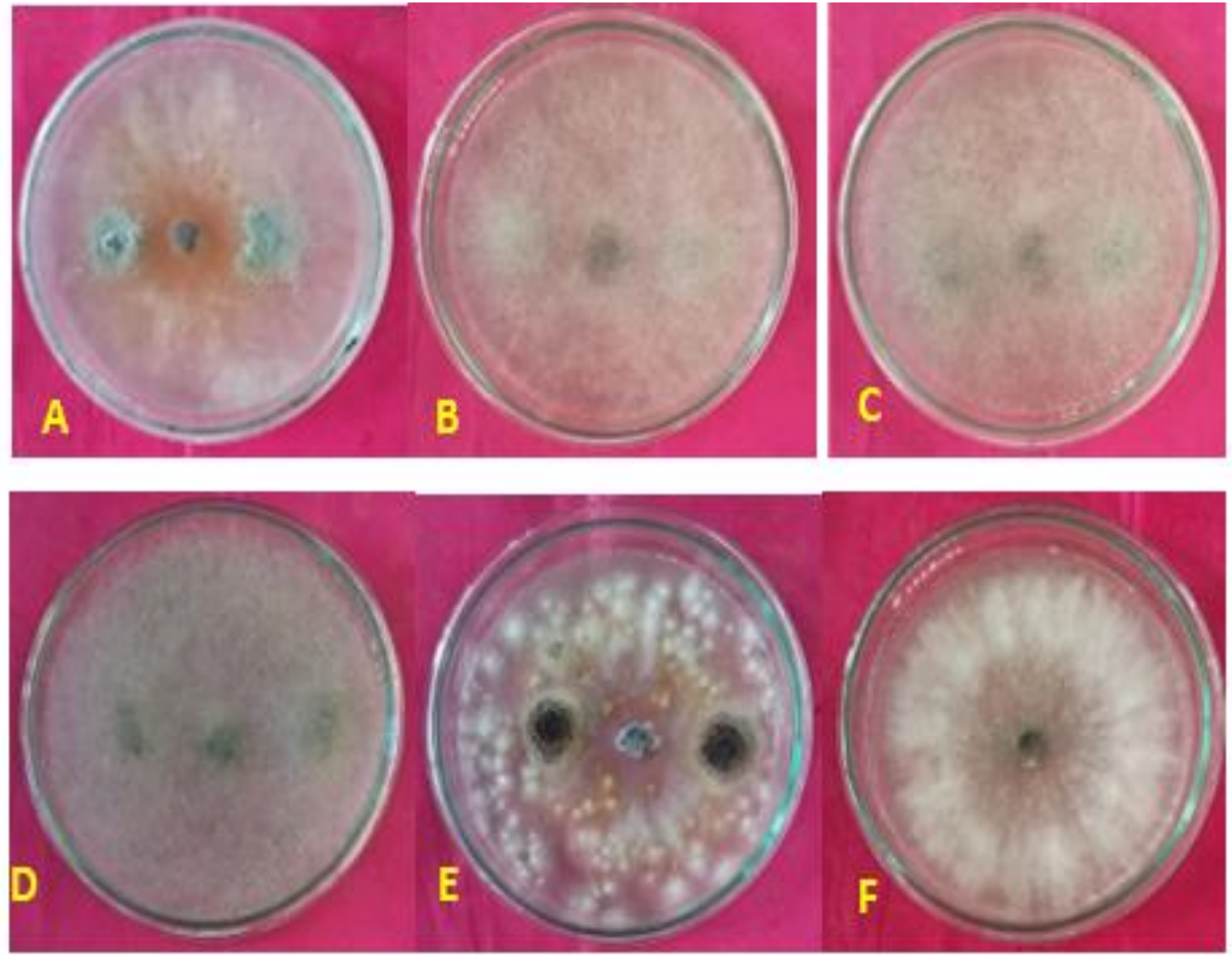
Fig.5 The results of the inhibitory treatment of exophytic and endophytic fungi against pathogens (Lasiodiplodia theobromoe) in vivo, 4 days after inoculation ( $\mathrm{A}=$ Trichoderma $\mathrm{sp} ., \mathrm{B}=$ Rhizopus sp. $10, \mathrm{C}=$ A. niger, $\mathrm{D}=$ Rhizopus sp. 9, $\mathrm{E}=$ Rhizopus sp.7), $\mathrm{F}=$ control with pathogen, and $\mathrm{F}=$ control without pathogen
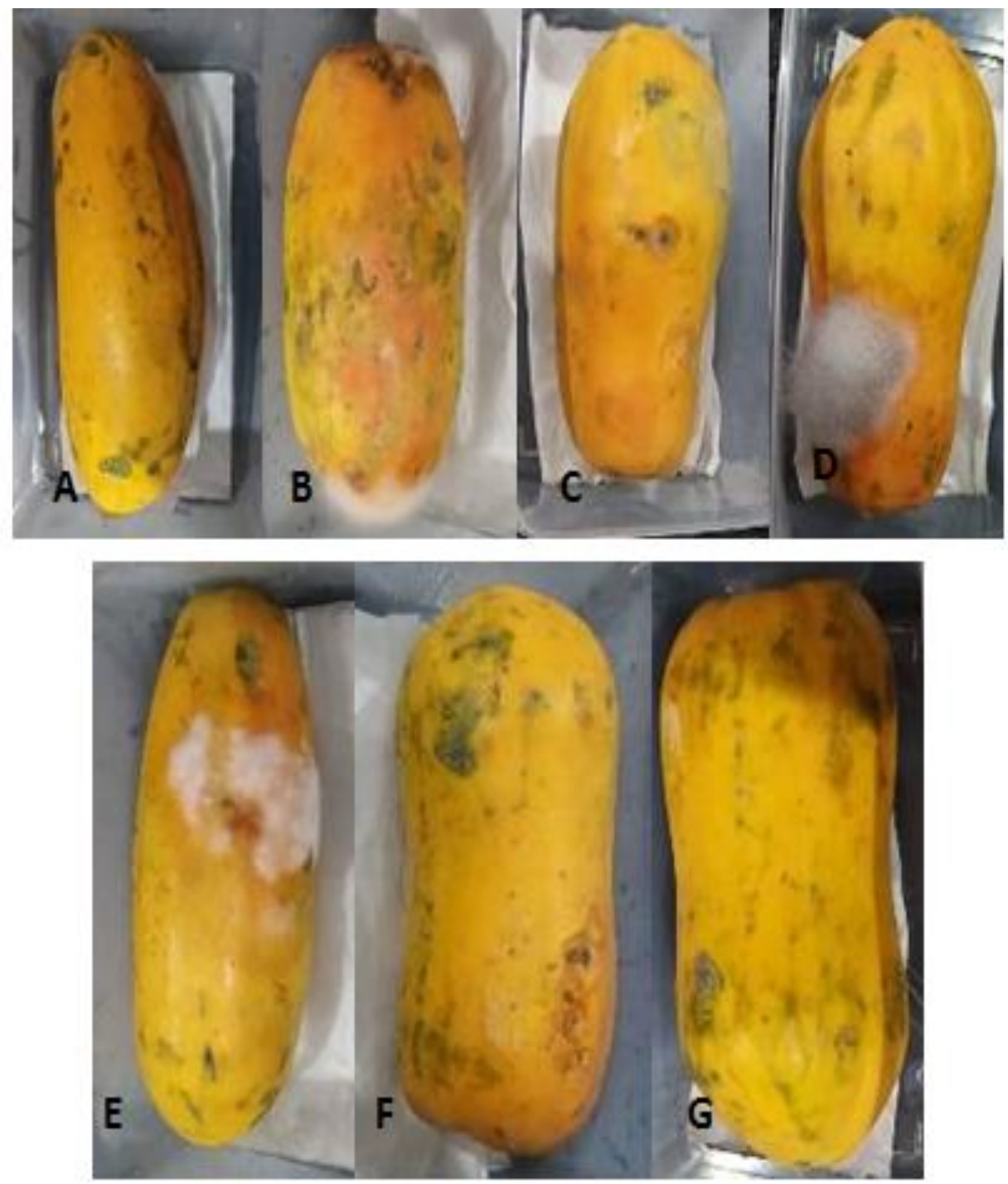

Invivo Inhibition of Exophytic and $82 \pm 2.44 \%$, then B (Rhizopus sp. 10) was Endophytic Fungi $67 \pm 4.00 \%$, treatment D (Rhizopus sp. 9) was $54 \pm 3.74 \%$, treatment E (Rhizopus sp. 7), and

The results of the in vivo inhibition of exophytic and endophytic fungi showed that the highest inhibitory power was obtained from treatment E (Trichoderma sp.) of $95 \pm 4.47$ not significantly different from the control (without pathogen) of $94 \pm 3.74 \%$, followed by treatment $\mathrm{C}$ (A.niger) was finally the smallest control with pathogen treatment (Table 5). It turns out that only Trichoderma sp. which showed the best inhibition in vivo. This inhibition occurs either antibiosis (because there is a zone of inhibition) or competitively because it fills the space of the Petri dish. 
Visually, it can be seen in Figure 5, after 4 days of inoculation it appears that only treatment A (Trichoderma sp.) gave the best results and hopes to be used as an antagonist fungus, namely as a biological agent.

Trichoderma sp. especially asexual fungi which are present in all types of agricultural soil and also in rotting wood. Antagonistic activity of Trichoderma species indicates that it can parasitize many soil and foliage borne pathogens. Fungi are also decomposers of cellulose waste materials. Recent discoveries have shown that fungi not only act as biocontrol agents, but also stimulate plant resistance, as well as plant growth and development resulting in increased crop production. Biocontrol activity involving mycoparasitism, antibiotic and nutrient competition, also induces a defense response or systemic resistance response in plants. This response is an important part of Trichoderma in the biocontrol program. Currently, Trichoderma spp., is used to control plant diseases in sustainable disease management systems (Naher et al., 2014). According to Ghazanfar et al., (2018) stated that new technologies in all fields of agriculture have increased agricultural production, but some modern practices affect the environment. A recent challenge faced by advanced agriculture is to achieve higher yields in an environmentally sound manner. Therefore, it is necessary to immediately find an environmentally friendly solution. Among the various types of species used as biocontrol agents, Trichoderma is widely used as a biocontrol agent against various types of plant pathogens. Trichoderma sp. recent studies have shown that this fungus not only acts as a biocontrol agent but also stimulates plant resistance, plant growth and development which has an impact on increasing crop production. Antagonistic activity involves mycoparasitism, antibiotics, competition for nutrients and also induces systemic resistance in plants.
Among other biocontrol mechanisms, antibiosis, competition, and mycoparasitism are among the main features by which microorganisms, including Thrichoderma, react to the presence of other competitive pathogenic organisms, thereby preventing or inhibiting their development. Stimulation of each process involves the biosynthesis of targeted metabolites such as growth regulators, enzymes, siderophores, antibiotics, etc. The biological control activity of Trichoderma spp. and describe recent advances in demonstrating the ecological significance of Trichoderma at the biochemical and molecular level in the rhizosphere as well as the benefits of symbiosis with host plants in terms of physiological and biochemical mechanisms. An applicative point of view, given here strongly supports the possibility to use Trichoderma as a safe, environmentally friendly and effective biocontrol agent for various plant species (Sood et al., 2020).

Based on the results and discussion above, it can be concluded as follows: The results of microscopic identification of rot disease in papaya fruit are caused by the fungus Lasiodiplodia theobromae. The most exophytic fungi found in the study were Rhizopus sp. as many as 69 isolates, followed by Aspergillus niger as many as 6 isolates, only Actinomyces israelii only 6 isolates while the other Actinomycetes (Actinomadura cremea, Streptomeces sp., and Micromonospora sp.) each had one isolate. While the endophytic fungi were found Rhizopus sp. as many as 30 isolates, followed by $A$. niger with 18 isolates, and finally Agromyces ramosus (Actinomycetes) and Trichoderma sp, each with 3 isolates. The highest prevalence was obtained from the fungus Rhizopus sp. The diversity index and dominance index on exophytic microbes were obtained at 3.549 and 0.408 , respectively. The index of diversity and dominance of 
endophytic microbes were 3.103 and 0.574 , respectively. The results of the analysis of the inhibitory power of exophytic and endophytic microbes in vitro, it turns out that almost all have competitive inhibition as well as Trichoderma sp. which has a zone of inhibition means that it is antibiotic and also competitive. Most Actinomycetes have no inhibitory power against pathogens (L.theobromae). The results of the in vivo inhibition test showed that the highest and best inhibitory power was obtained from treatment E (Trichoderma sp.).

\section{Acknowledgements}

Authors wish to thank to the Rector of Udayana University for their assistance and the opportunity given so that research can be resolved, Dean of the Faculty of Agriculture, Udayana University, and Chairman of the Institute for Research and Community Service Udayana University, for their help and cooperation so that research can be funded to completion.

\section{References}

Adriani, R. 2020. Identifikasijamur penyebabpenyakit pascapanen pada buahstroberi (Fragaria sp.) di KabupatenSolok. Fakultas Pertanian Universitas Anadalas Padang.

Alvarez, A. M. and W. T. Nishijima, 1987. Post harvest diseases of papaya. Plant Disease 71 8: . 681-686.

Aminah, St. N. dan Supraptini. 2003. Jamur pada buah-buahan,sayuran, kaki lalat dan lingkungan di pasar tradisional dan swalayan. Ekologi Kesehatan 2(3): 299305.

Barnett, H. L. and B. B. Hunter. 1998. Illustrated Genera of Imperfect Fungi. APS Press. The American Phytopathological Sociey. St Paul, Minnesota.

Diana, N. 2018. Identifikasijamur Rhizopus sp. pada buah papaya jingga. Program Diploma DIII Analisis Kesehatan, Sekolah Tinggi Ilmu Kesehatan, InsanCendikiaMedika, Jombang. KaryaTulisIlmiah. 5 hal.

Dolar, F. S. 2001. Antagonistic effect of Aspergillus melleus Yukawa on soilborne pathogens of Chickpea. TarimBilimleriDergisi, 8(2): 167-170.

Ferianita-Fachrul, M., H. Haeruman, dan L. C. Sitepu. 2005. Komunitas Fitoplankton Sebagai Bio-Indikator Kualitas Perairan Teluk Jakarta. FMIPA-Universitas Indonesia Depok.

Indrawati. G., R. A. Samson, K. Van den TweelVermeulen, A. Oetari dan I. Santoso. 1999. Pengenalan Kapang Tropik Umum. Yayasan Obor Indonesia. Universitas Indonesia (University of Indonsia Culture Collection) Depok, Indonsia dan Centraalbureau voor Schirmmelcultures, Baarn, The Netherlands.

Indriyani N. L. P., Affandi dan D. Sunarwati. 2008. Pengelolaan Kbeun Pepaya Sehat. Balai Penelitian Tanaman Buah Tropika Pusat Penelitian dan Pengembangan Hortikultura Badan Penelitian dan Pengembangan Pertanian.

Langvad, F. 1980. A simple and rapid method for qualitative and quantitative study of the fungal flora of leave. Canadian Journal of Botany 26: 666-670.

Misra A. K., and O. M. Prakash. 2016. Fungal Diseases of Papaya in India. Central Institute of Horticulture for Northern Plains Rehmankhera, P.O. Kokori, Distt, Lucknow (U.P.).

Mojica-Marin, V., H. A. Luna-Olvera, C. Fco, Sandoval-Coronado, B. Pereyra- Alférez, H. Lilia, Morales-Ramos, E. Carlos, Hernández-Luna and G. O. AlvaradoGomez. 2008. Antagonistic activity of selected strains of Bacillus thuringiensis against Rhizoctonia solani of chilli pepper. African Journal of Biotechnology, 7 (9): 1271-1276.

Mojica-Marin, V., H. A. Luna-Olvera, C. Fco, Sandoval-Coronado, B. Pereyra- Alférez, H. Lilia, Morales-Ramos, E. Carlos, 
Hernández-Luna and G. O. AlvaradoGomez. 2008. Antagonistic activity of selected strains of Bacillus thuringiensis against Rhizoctonia solani of chilli pepper. African Journal of Biotechnology, 7 (9): 1271-1276.

Naher, L., U. K. Yusuf, A. Ismail and K. Hossain. 2014. Trichodermaspp.: A Biocontrol Agent for Sustainable Management of Plant Diseases. Pak. J. Bot., 46(4): 1489-1493.

Odum, E. P. 1971. Fundamentals of Ecology. Third Edition. W. B. Saunders Company. Philadelphia, Toronto, London. Toppan Company, Ltd. Tokyo, Japan.

Pirzan, A. M., dan P. R. Pong-Masak. 2008. Hubungan Keragaman Fitoplanktondengan Kualitas Air di Pulau Bauluang, Kabupaten Takalar, Sulawesi Selatan. Biodiversitas, 9 (3) 217-221.

Pitt, J. I. and A. D. Hocking. 1997. Fungi and Food Spoilage. Blackie Avademic and Professional. Second Edition. LondonWeinhein-New York-Tokyo-MelbouneMadras.

Rad, J. E., M. Manthey and A. Mataji. 2009. Comparison of Plant Species Diversity with Different Plant Communities in Deciduous Forests. Int. J. Environ. Sci. Tech, 6(3): 389-394.

Rahmawati, D., Samrin dan A. R. Kumala Sari. 2020. Keragaman Hama dan MusuhAlami pada PertanamanPadi di Wawotobi, Sulawesi Tenggara. PenelitianPertanianTanamanPangan 4(3) 145-151.

Samson, R. A., E. S. Hoekstra, and C. A. N. Van Oorschot. 1981. Introduction to FoodBorne Fungi. Centraal bureau VoorSchimmel cultures. Institute of the Royal Netherlands. Academic of Arts and
Sciences.

Sood, M., D. Kapoor, V. Kumar, M. Sheteiwy, M. Ramakrishnan, M. Landi, F. Araniti and A. Sharm. 2020. Trichoderma: The "Secrets" of a Multitalented Biocontrol Agent. Review. Plants 9: 1-25.

Sudarma, I M., N. N. Darmiati and N. W. Suniti. 2019. Fungus and Actinomycetes Diversity of Exophytic and Endophytic in Red Grape and its Inhibition Ability to Pathogen Aspergillus niger(Caused Rot Fruit Grape). Int.J.Curr.Microbiol.App.Sci 8(10): 2442-2451.

Sudarma, I M., N. W. Suniti and N. N. Darmiati. 2020. Use of exophytic microbial on the controlof fruit rot diseases of mango (Lasiodiplodia theobromae). Int.J.Curr.Microbiol. App.Sci 9(4): 845854.

Sudarma, I M., N. W. Suniti, N. N. Darmiati and I G. N. Bagus. 2018. The Diversity of Exophytic Fungus in Sugar-Apple Plant and their Inhibition Ability on Lasiodiplodia theobromae (Cause of Srikaya Fruit Rot) in Vitro. Int. J. Curr. Res. Biosci. Plant Biol. 5(10), 32-38.

Tauruslina, E, Trizelia, Yaherwandi dan Hasmiandy, H. 2015. Analisiskeanekaragamanhayatimusuhalam i pada eksosistem pada sawah di daerahendemik dan non - endemic WerengBatangCokelatNilaparvatalugens di Sumatera Barat. Pros Sem NasMasyBiodivIndon 1(3): 581 - 589.

Ventura, J. A., H. Costa and J. da S. Tatagiba. 2004. Papara Diseases and Integrated Control. In Diseases of Fruit and Vegetables. Diagnosis and Management, Vol. II. Kluwer Academic Publishers. New York, Boston, Dordrecht, London, Moscow.

\section{How to cite this article:}

I Made Sudarma, Ni Nengah Darmiati and dan Ni WayanSuniti. 2021. Control of Papaya Rot Disease by Using Exophytic and Endophytic Fungi Which is Environmentally Friendly. Int.J.Curr.Microbiol.App.Sci. 10(09): 600-612. doi: https://doi.org/10.20546/ijcmas.2021.1009.069 